\title{
A STUDY ON BUILDING CONSTRUCTION INVESTMENT FEASIBILITY
}

\author{
Meriana Wahyu Nugroho, Lyya Supriono \\ Department of Civil Engineering, Hasyim Asy'ari University, Indonesia \\ Department of Civil Engineering, Merdeka University, Indonesia \\ E-mail: meriananugroho@unhasy.ac.id
}

\begin{abstract}
The level of society's awareness on education is very high. The society's enthusiasm to take a higher education is enormous. Every year the society's interest in joining Hasyim Asy'ari University of Tebuireng Jombang is increasing. For this reason, Hasyim Asy'ari University of Tebuireng Jombang plans to add the classes by constructing new buildings that can accommodate more students each year. Every construction certainly has a risk. To anticipate this, a feasibility study is carried out at the early stages of construction planning so that later the construction runs well. There are three methods used to analyze investment feasibility, namely, Net Present Value (NPV) method, Benefit Cost Ratio (BCR) method and Internal Rate of Return (IRR) method. Besides using those methods, the payback period for the building construction project of Hasyim Asy'ari University of Tebuireng Jombang is also calculated. Based on the results of the analysis conducted, it was found that the construction of Hasyim Asy'ari University of Tebuireng Jombang was feasible to be carried out referring to the $N P V$ and $B / C$ values which were higher than one and the IRR value was higher than MARR and the payback period was for 7 years and 5 months. Thus, the investment project is declared feasible to proceed.
\end{abstract}

Keywords: Invesment, Nett Present Value, Benefit Cost Ratio, Internal Rate of Return, Payback Period

\section{Introduction}

The increase of society's interest in taking pesantren-based education makes Hasyim Asy'ari University of Tebuireng Jombang plan to build a campus building so that it can accommodate more students each year.

Every development, of course, has many obstacles to be faced. To anticipate this, it is necessary to conduct a study on the feasibility of the lecture building construction at Hasyim Asy'ari University of Tebuireng Jombang.

The methods used are Net Present Value (NPV) method, Internal Rate of Return (IRR) method, Benefit Cost Ratio (BCR) method and Payback Period in the payback that has been used in carrying out the construction.

Several previous studies using the same methods in assessing the feasibility of investment. A study conducted in the housing of green semanggi magrove of Surabaya showed the analysis result meaning that investment can be accepted with the increase of the maximum investment cost limit up to $25 \%$ [1]. Meanwhile, the financial feasibility study for the construction of a parking building in the boarding school of Amanatul Ummah in Kembang Belor village, Pacet sub-district, Mojokerto district showed that an investment study was feasible to be implemented because the value of NPV was higher than 0 , the value of BCR was higher than 1, and the value of IRR was higher than 1 [2]. Another study on the investment feasibility of housing construction concluded that viewed from a financial perspective, it was declared not feasible if the income decrease was $10 \%$ [6]. The result of a study on the feasibility of hotel investment in West Kalimantan showed 
that the NPV value was 23.025.467.095 and the IRR value was higher than the prevailing interest rate, and the PP value was lower than the investment period of the hotel, so it is estimated that the investment would experience profits [7]. Housing construction of Nuansa Beringin had met the predetermined indicators and was declared feasible to do [8]. A study on the development of investment at Dili University in Timor-Leste had result meaning that viewed from financial aspect the construction of the building and its supporting facilities was feasible to be implemented [9].

The financial feasibility analysis of the flat development provided two alternative analysis, in which alternative 1 showed that inflation changes did not affect the assessment of financial feasibility and alternative 2 showed that NPV value was higher, the payback period was faster, IRR value decreased and the BCR remained constant [10]. Analysis of a hotel in Maluku showed that a positive NPV value was Rp. 7.661.715.244 and an IRR value was $21.67 \%$ which indicated that the investment in this project was profitable and good to be implemented [11]. The assessment of the hospital building of Dr. Karyadi Semarang was feasible to be implemented because it had met 4 indicators [12]. The analysis of flat housing investment was feasible because the inflation rate was used at $5.75 \%$ indicating that feasibility indicators consisting of positive NPV value, BCR value was higher than 1 (one), and IRR value was higher than $5.75 \%$ (inflation) [13].

\section{Methodology}

This study was to determine whether the project was feasible or not to be implemented viewed from a financial perspective. The construction costs represent all of costs incurred to complete the construction, both direct costs and indirect costs. Direct costs are costs that are directly related to the volume of work. Indirect costs are costs that are not directly related to the physical volume of the project. It was Economic Analysis System, according to Donald G. Newnan [2].

\section{Hasil dan Pembahasan}

The results of the difference between income and project costs having been used based on the analysis carried out can be seen in the Table 1 .

Table 1. Table of Net Present Value (NPV)

\begin{tabular}{cccc}
\hline Th & $(\mathrm{P} / \mathrm{F}), 12 \%, \mathrm{n}$ & Income $(\mathrm{Rp})$ & $\mathrm{NPV}(\mathrm{Rp})$ \\
\hline 0 & 1.00 & $-3,600,000,000$ & $-3,600,000,000$ \\
1 & 0.89 & $637,000,000$ & $-3,031,250,000$ \\
2 & 0.80 & $752,956,456$ & $-2,430,997,723$ \\
3 & 0.71 & $763,934,967$ & $-1,887,243,903$ \\
4 & 0.64 & $775,064,053$ & $-1,394,676,685$ \\
5 & 0.57 & $786,345,723$ & $-948,483,004$ \\
6 & 0.51 & $797,782,013$ & $-544,301,808$ \\
7 & 0.45 & $809,374,986$ & $-178,181,668$ \\
8 & 0.40 & $821,126,732$ & $153,457,647$ \\
9 & 0.36 & $833,039,372$ & $453,859,996$ \\
10 & 0.32 & $845,115,053$ & $725,964,425$ \\
11 & 0.29 & $857,355,950$ & $972,433,773$ \\
12 & 0.26 & $869,764,271$ & $1,195,680,598$ \\
13 & 0.23 & $882,342,250$ & $1,397,890,668$ \\
14 & 0.20 & $895,092,153$ & $1,581,044,257$ \\
15 & 0.18 & $908,016,276$ & $1,746,935,436$ \\
16 & 0.16 & $921,116,946$ & $1,897,189,563$ \\
17 & 0.15 & $934,396,521$ & $2,033,279,128$ \\
18 & 0.13 & $947,857,391$ & $2,156,538,115$ \\
19 & 0.12 & $961,501,979$ & $2,268,175,010$ \\
20 & 0.10 & $975,332,740$ & $2,369,284,600$ \\
\hline
\end{tabular}

Source : Analysis result 


\section{JCEJournal Innovation of Civil Engineering}

Vol. 1, No. 1, pp. 28-31, 2020

Submit: $10-03-2020$

Accepted: 21-04-2020 |

Publish: 24-04-2020 |

From the table above, it can be seen that the NPV value is Rp. 2,368,248,600.00 meaning that the investment value is declared profitable.

a) Value of Benefits - Cost Analysis

Table below presents the result of the comparison between costs and benefits obtained within a certain period of time.

Table 2. Table of Benefits Cost Ratio

\begin{tabular}{cccc}
\hline Th & $(\mathrm{P} / \mathrm{F}), 12 \%, \mathrm{n}$ & PV Costs & PV Income \\
\hline 0 & 1.00 & $3,600,000,000$ & \\
1 & 0.89 & $243,750,000$ & $812,500,000.00$ \\
2 & 0.80 & $217,633,929$ & $817,886,205.58$ \\
3 & 0.71 & $194,316,008$ & $738,069,827.90$ \\
4 & 0.64 & $173,496,435$ & $666,063,653.15$ \\
5 & 0.57 & $154,907,532$ & $601,101,212.85$ \\
6 & 0.51 & $138,310,296$ & $542,491,491.79$ \\
7 & 0.45 & $123,491,336$ & $489,611,475.51$ \\
8 & 0.40 & $110,260,121$ & $441,899,436.53$ \\
9 & 0.36 & $98,446,537$ & $398,848,885.65$ \\
10 & 0.32 & $87,898,694$ & $360,003,122.37$ \\
11 & 0.29 & $78,480,976$ & $324,950,324.81$ \\
12 & 0.26 & $70,072,300$ & $293,319,125.40$ \\
13 & 0.23 & $62,564,554$ & $264,774,624.39$ \\
14 & 0.20 & $55,861,209$ & $239,014,797.38$ \\
15 & 0.18 & $49,876,079$ & $215,767,258.04$ \\
16 & 0.16 & $44,532,214$ & $194,786,340.59$ \\
17 & 0.15 & $39,760,905$ & $175,850,470.51$ \\
18 & 0.13 & $35,500,808$ & $158,759,794.75$ \\
19 & 0.12 & $31,697,150$ & $143,334,045.88$ \\
20 & 0.10 & $28,301,027$ & $129,410,616.85$ \\
\hline
\end{tabular}

Source: Analysis results

From the comparison between costs and benefits, the $\mathrm{B} / \mathrm{C}$ value is 1.42 which is higher than 1. This indicates that the development project can provide benefits because the $\mathrm{B} / \mathrm{C}$ value is higher than one.

b) Value of Internal Rate of Return

According to Robert J. Kodoatie [4], the amount of interest rate makes expenses and income equal. Based on the interpolation method implemented, it is obtained that the IRR value is higher than $12 \%$, so it can be said that the investment is feasible to be done.

c) Payback Period

Payback period based on the calculation having been done indicates that the return on invesment was foe 7 years and 5 months. The following table presents the calculation of payback period.

Table 3. Table of Payback Period (PP)

\begin{tabular}{cccc}
\hline Th & $(\mathrm{P} / \mathrm{F}), 12 \%, \mathrm{n}$ & $\mathrm{PV}$ & $\mathrm{NPV}$ \\
\hline 0 & 1.00 & $-3,600,000,000$ & $-3,600,000,000$ \\
1 & 0.89 & $568,750,000$ & $-3,031,250,000$ \\
2 & 0.80 & $600,252,277$ & $-2,430,997,723$ \\
3 & 0.71 & $543,753,820$ & $-1,887,243,903$ \\
4 & 0.64 & $492,567,218$ & $-1,394,676,685$ \\
5 & 0.57 & $446,193,681$ & $-948,483,004$ \\
6 & 0.51 & $404,181,196$ & $-544,301,808$ \\
7 & 0.45 & $366,120,140$ & $-178,181,668$ \\
8 & 0.40 & $331,639,315$ & $153,457,647$ \\
9 & 0.36 & $300,402,349$ & $453,859,996$ \\
10 & 0.32 & $272,104,429$ & $725,964,425$ \\
11 & 0.29 & $246,469,348$ & $972,433,773$
\end{tabular}




\begin{tabular}{cccc}
\hline Th & $(\mathrm{P} / \mathrm{F}), 12 \%, \mathrm{n}$ & $\mathrm{PV}$ & $\mathrm{NPV}$ \\
\hline 12 & 0.26 & $223,246,825$ & $1,195,680,598$ \\
13 & 0.23 & $202,210,070$ & $1,397,890,668$ \\
14 & 0.20 & $183,153,589$ & $1,581,044,257$ \\
15 & 0.18 & $165,891,179$ & $1,746,935,436$ \\
16 & 0.16 & $150,254,127$ & $1,897,189,563$ \\
17 & 0.15 & $136,089,565$ & $2,033,279,128$ \\
18 & 0.13 & $123,258,987$ & $2,156,538,115$ \\
19 & 0.12 & $111,636,896$ & $2,268,175,010$ \\
20 & 0.10 & $101,109,590$ & $2,369,284,600$ \\
\hline \multicolumn{5}{l}{ Source: Analysis result }
\end{tabular}

\section{Conclusion and Suggestion}

The result of this study showed that the NPV value was Rp. 2,368,248,600,-. It can be concluded that investment in the construction of building B at Hasyim Asy'ari University of Tebuireng Jombang is declared profitable, and investment is strongly recommended to continue because the value of $\mathrm{B} / \mathrm{C}$ was 1.42 which was higher than 1 and is worth continuing. Investments in the construction of building $B$ if the construction uses funds with an interest rate of $12 \%$ are still quite profitable and feasible because the IRR value is greater than $12 \%$ with a payback period of only 7 years and 5 months.

\section{References}

[1] A. Prastiwi and C. Utomo, "Analisa Investasi Perumahan Green Semanggi Mangrove Surabaya," Tek. Pomits, vol. 2, no. 2, pp. D191-D196, 2013.

[2] Dugdale R.H., 1980, Surveying, 3rd Edition, George Godwin Limited, London.

[3] Karnila, 2012. Analisis Nilai Hasil Terhadap Biaya pada Proyek Kontruksi (Studi kasus Pada Proye $k$ Pembangunan

[4] Kodoatie, Robert j., 1994, “Analisa Ekonomi Teknik”, Andi Yogyakarta, Yogyakarta.

[5] M. F. Lisan, "Studi Kelayakan Finansial Pembangunan Gedung Parkir Ponpes Amanatul Ummah Desa Kembang Belor Kecamatan Pacet Mojokerto," J. Tek. Sipil UNTAG Surabaya, vol. 8, no. 2, pp. 191-206, 2015.

[6] F. Utu, "Studi kelayakan investasi pengembang perumahan," vol. 3, no. 2, pp. 44-54, 2017.

[7] E. S. Widiya Putri, Naomi Nessyana Debataraja, "Analisis Kelayakan Pada Investasi Hotel Xy Di Kalimantan Barat,” Bul. Ilm. Mat, Stat, dan Ter., vol. 08, no. 2, pp. 255-262, 2019.

[8] H. Y. Ari, Zainuri, and Winayati, "Analisis Investasi Pada Pembangunan Perumahan Nuansa Beringin,” J. Tek., vol. 13, no. 2, pp. 120-127, 2019.

[9] I. Elisa, I. G. B. Wiksuana, L. Gede, and S. Artini, "Study Kelayaan Pembangunan Investasi Dili Undil di Timor Leste," vol. 9, pp. 506-519, 2014.

[10]M. F. Subkhan, "Analisis kelayakan finansial pembangunan rusunawa," J. Tek. sipil Prokons, vol. 8, no. 1, pp. 93-102, 2014.

[11]S. R. Jemmy Kristianto, Rosmitha Indah, Herry P. Chandra, "Analisa Kelayakan Investasi Hotel Di Maluku Tenggara Yang Menerapkan Konsep Energy Efficiency Dan Indoor Air Health," J. Dimens. Pratama Tek. Sipil, vol. 5, no. 1, pp. 1-9, 2016.

[12]H. A. A and B. Laksito, "Analisis investasi bangunan gedung (Studi Kasus Pada Proyek Pembangunan Gedung Rawat Inap RSUP Dr. Kariadi Semarang)," e-Jurnal MATRIKS Tek. SIPIL, no. eISSN 2354-8630, pp. 297-304, 2014.

[13]Y. Arianti, "Analisis kelayakan ekonomi rumah susun sederhana pekanbaru," J. Sains dan Teknol., vol. 3, no. 1, pp. 16-22, 2013. 